\title{
Impact of High Temperature and Pressure to Steel Passivation in $\mathrm{CO}_{2}$ Atmosphere
}

\author{
Mojca Slemnik* \\ University of Maribor, Faculty of Chemistry and Chemical Engineering, Smetanova 17, 2000 Maribor, Slovenia \\ * Corresponding author: E-mail: mojca.slemnik@um.si
}

Received: $12-10-2020$

\begin{abstract}
The corrosion behaviour of AISI 347 in $0.1 \mathrm{M}$ sulfuric acid at temperatures 50 and $75^{\circ} \mathrm{C}$ and pressures up to 300 bar in a $\mathrm{CO}_{2}$ atmosphere was studied by surface analysis and electrochemical methods. Corrosion reactions in which $\mathrm{CO}_{2}$ is present accelerate the formation of a protective $\mathrm{FeCO}_{3}$ layer, but the success of such a passivation depends on the saturation concentration and the corresponding temperature. Significantly better results compared to untreated steels were obtained at lower temperatures by increasing the pressure. To explain the differences in corrosion rates between samples, the activation energy for the layer dissolution was also discussed. It can be assumed that the compressibility of the $\mathrm{CO}_{2}$ at different pressures has an influence on the formation of the protective iron carbonate layer and its properties and thus to on the corrosion behaviour.
\end{abstract}

Keywords: Stainless steel, EIS, $\mathrm{CO}_{2}$ corrosion, high pressure

\section{Introduction}

The steel AISI 347 is generally used in extreme conditions, e.g. aggressive media, at high temperatures and/or high pressures, mostly in pipeline systems, in the gas industry, especially for industrial gas cylinders, etc. It belongs to the group of steels with the low carbon content, which can be additionally protected with inhibitors or coatings. ${ }^{1}$ The niobium content improves the mechanical properties of the steel by increasing hardness and the corrosion properties by reducing pitting. ${ }^{2}$ It has a great affinity to carbon, which precipitates as a carbide. Niobium carbides are more stable than those of chromium, they remove carbon from the solid solution and stabilize the steel. ${ }^{3} \mathrm{Ni}$ obium also refine the grain size, promotes the formation of chromium oxides and accelerates the formation of an iron oxide enriched passive layer in the outer layer and chromium, manganese and iron oxides in the inner layer at high temperature. ${ }^{4}$ Carbon dioxide is useful as a supercritical fluid in several chemical processes as it changes its properties such as density, diffusivity, viscosity, compressibility, and surface tension by changing temperature and/or pressure. When it is used in a corrosive environment, it changes its parameters such as $\mathrm{pH}$, partial pressure, temperature, concentration, compressibility etc. and influences the formation of a protective passive layer on the surface of the metal and thus its protective properties. To reduce the cor- rosion rate, some authors suggest different coatings, pre-passivation ${ }^{5-8}$ or the use of efficient inhibitors ${ }^{9-11}$ for steel in $\mathrm{CO}_{2}$ and also aggressive environments. Not many $\mathrm{CO}_{2}$ corrosion studies have been carried out on low carbon steels, ${ }^{12}$ but the fact is that steel exposed to the $\mathrm{CO}_{2}$ environment triggers a spontaneous passivation process as it causes the formation of the $\mathrm{FeCO}_{3}$ layer that protects the metal surface and reduces the corrosion rate.

Dugstad ${ }^{13-16}$ explains how the term $\mathrm{CO}_{2}$ corrosion covers a wide range of electrochemical mechanisms and complex processes. The interaction between protective $\mathrm{Fe}-$ $\mathrm{CO}_{3}$ layer formation, corrosion rate and iron ion concentration in water was described in detail. $\mathrm{CO}_{2}$ corrosion reactions are divided into anodic and cathodic processes. It was also found that ferritic-perlitic microstructures can be covered with a porous carbide phase which was related to high carbon content on the steels. In principle, corrosion reactions in $\mathrm{CO}_{2}$ create a chemical environment that accelerates the formation of iron carbonate, which is often oxidized in air. ${ }^{17}$ Such a layer is formed by the precipitation of iron carbonate when its saturation concentration is exceeded. ${ }^{18,19}$ The concentrations of iron and carbonate ions must locally exceed the solubility limit. The precipitation rate is low at low temperatures, so that in this case a very small amount of layer is formed and a higher temperature is required for process efficiency. If the rate of iron 
and carbon precipitation is equal to or higher than the corrosion rate, a dense protective layer is formed, but if the corrosion process is faster, the layer becomes porous and unprotective. ${ }^{20}$ Therefore, special attention has been paid to the study of iron carbonate solubility under different conditions. W. Sun and S. Nešić ćl $^{1}$ developed a uniform equation for iron carbonate solubility that is valid for a wide range of parameters and is based on literature data. In the case of $\mathrm{CO}_{2}$ corrosion, however, many effects must be taken into account. ${ }^{22}$ As expected, the temperature increases the corrosion rate, especially at low $\mathrm{pH}$ values, when no precipitation of iron carbonate can occur. On the other hand, the solubility of iron carbonate increases with rising temperature, and when it finally exceeds the solubility limit of iron carbonate, its protective scale formation reduces the rate of corrosion. In addition to temperature and many other effects, the effect of the $\mathrm{CO}_{2}$ partial pressure was also investigated. ${ }^{23} \mathrm{Y}$. Sun and $\mathrm{S}$. Nešic ${ }^{24}$ studied an increase in $P_{\mathrm{CO} 2}$ from 3 to 20 bar and concluded, that $P_{\mathrm{CO} 2}$ generally leads to an increase in the corrosion rate due to an increased concentration of $\mathrm{H}_{2} \mathrm{CO}_{3}$, which further accelerates the cathodic reaction and thus the corrosion rate. However, when the conditions for the formation of iron carbonate are favourable, a higher $P_{\mathrm{CO} 2}$ value increases the carbonate ion concentration, which further leads to higher supersaturation and scale precipitation. ${ }^{25} \mathrm{Y}$. Zhang et al. ${ }^{26}$ studied $\mathrm{CO}_{2}$ corrosion behaviour between low partial pressure (1 $\mathrm{MPa})$ and supercritical conditions $(9.5 \mathrm{MPa})$ at various temperatures (from 50 to $130^{\circ} \mathrm{C}$ ) and immersion times. It was concluded that the change in partial pressure does not alter the corrosion mechanism, but only affects the corrosion rate, so that the rate is higher under supercritical conditions. X. Li et al. ${ }^{27}$ investigated the nature of corrosion scales in extremely aggressive environments at high temperature and $\mathrm{CO}_{2}$ high pressure and found that the corrosion resistance performance of corrosion scales decreases with increasing temperature and $\mathrm{CO}_{2}$ pressure, finding the decreasing pitting and repassivation potential with increasing density and diffusivity of the acceptor in the scales. Z. M. Wang et al. ${ }^{28}$ succeeded in the in situ observation of the $\mathrm{CO}_{2}$ corrosion process under high pressure from active dissolution, the formation of a defective corrosion layer up to local layer dissolution and pitting.

In general, corrosion protection methods include the use of corrosion resistant materials, coatings, corrosion inhibitors, electrochemical protection, rust preventing oils or greases and surface treatments. ${ }^{29}$ The most natural and spontaneous phenomenon in the surface treatment of metals is passivation process, which can also be accelerated with a suitable approach. In our previous study we worked on improving the surface passivation at $25^{\circ} \mathrm{C}$ by forming a stable protective layer of iron carbonate by exposing the system only to elevated pressures of up to 300 $\mathrm{bar}^{30}$ in acidic environment. In the following we were interested in the corrosion behaviour of steel in sulphuric acid at elevated pressures of up to 300 bar and simultane- ously elevated temperatures of 50 and $75{ }^{\circ} \mathrm{C}$, since AISI 347 is commonly used for industrial gas cylinders operating under high pressure. We also investigated the temperature dependence and the values of the activation energies required for the dissolution process of protective layer.

\section{Experimental}

\section{1. Material and Sample Preparation}

Stainless steel AISI 347 made in Železarna Ravne, Slovenia, has been investigated, with following chemical composition in wt\%: Fe $69.882 \%$, C $0.05 \%$, Si $0.53 \%$, Mn $1.32 \%$, P $0.024 \%$, S $0.024 \%$, Cr $17.95 \%$, Ni $9.66 \%$ in $\mathrm{Nb}$ $0.56 \%$.

Samples were mechanically polished with $400-1200$ grit abrasive paper, polished with diamond pastes to a mirror - like quality, and degreased in acetone, p.a. (Fluka).

The high pressure experiments were performed in a thermostated autoclave with $65 \mathrm{~mL}$ volume, which is designed for a maximum temperature of $200^{\circ} \mathrm{C}$ and pressure to 400 bar. The temperature was kept constant with the outdoor thermostat Lauda RC6 CP and measured with the Greisinger thermometer GMH 3230 with an accuracy of \pm $0.1{ }^{\circ} \mathrm{C}$. For the evacuation of the autoclave the vacuum pump with a provided underpressure of $3.45 \mathrm{~Pa}$ was used. $\mathrm{CO}_{2}$ was dosed into the autoclave with the pump PM101. The pressure was measured with the sensor Wika (PI) with an accuracy of $0.01 \mathrm{MPa}$.

Samples were immersed in $40 \mathrm{~mL}$ of $0.1 \mathrm{M} \mathrm{H}_{2} \mathrm{SO}_{4}$ prepared from $96 \%$ acid, p.a. (Carlo Erba), previously bubbled for $10 \mathrm{~min}$ with $\mathrm{CO}_{2}$ of $99.995 \%$ purity (Messer Slovenija). The autoclave was evacuated and charged with $\mathrm{CO}_{2}$ to the desired pressure. The solution was stirred with a magnetic stirrer at a frequency of $800 \mathrm{~min}^{-1}$ for 1 hour.

After pressure relief, the samples, which were already covered with the resulting layer, were analysed with the Sirion 400 NC (SEM - Scanning Electron Microscopy) and EDS (Energy Dispersive X-ray Spectroscopy) INCA 350 analyser.

\section{2. Electrochemical Tests}

The electrochemical measurements were performed in a standard three-electrode cell with sample as working electrode, a platinum counter electrode and reference SCE (standard calomel electrode, with the potential $+2,44 \mathrm{~V}$ vs. standard hydrogen electrode). The cell was filled with $300 \mathrm{~mL} 0.1 \mathrm{M}$ sulfuric acid. The data were collected with Electrochemical Interface Solartron1287 and Frequency Response Analyzer Solartron 1250.

The samples were stabilised at OCP (open circuit potential) until the system reached stability and then the impedance curves were recorded in the frequency range between $60 \mathrm{kHz}$ and $1 \mathrm{mHz}$. The amplitude of the excitation voltage was $10 \mathrm{mV}$. Measurements were made three times 
for each sample and the mean value was considered with the standard deviation max. 3\%.

Potentiodynamic curves from $0.6 \mathrm{~V}$ to $1.0 \mathrm{~V}_{\text {SCE }}$ were recorded at a sampling rate of $1 \mathrm{mVs}^{-1}$. All data were acquired and processed with the ZPlot, ZView, CorrWare and CorrView instruments developed by Scribner Associates, Inc. ${ }^{31}$

\section{Results and Discussion}

\section{1. Surface Analysis}

It is generally known that during $\mathrm{CO}_{2}$ corrosion of steel the system first leads to the formation of $\mathrm{H}_{2} \mathrm{CO}_{3}$ and further to the formation of $\mathrm{FeCO}_{3}$ (siderite): $26,32,33$

$$
\begin{aligned}
& \mathrm{CO}_{2}+\mathrm{H}_{2} \mathrm{O} \rightarrow \mathrm{H}_{2} \mathrm{CO}_{3} \\
& 2 \mathrm{H}_{2} \mathrm{CO}_{3}+2 e^{-} \rightarrow \mathrm{H}_{2}+2 \mathrm{HCO}_{3}^{-} \\
& \mathrm{HCO}_{3}^{-} \rightarrow \mathrm{H}^{+}+\mathrm{CO}_{3}^{2-} \\
& \mathrm{Fe} \rightarrow \mathrm{Fe}^{2+}+2 e^{-} \\
& \mathrm{Fe}^{2+}+\mathrm{CO}_{3}^{2-} \rightarrow \mathrm{FeCO}_{3}
\end{aligned}
$$

Layer growth is caused by precipitation after exceeding the saturation concentration under suitable conditions. Our samples, which were exposed to $\mathrm{CO}_{2}$ in a closed autoclave system under different pressure and temperature values, were covered with a layer whose morphology was further investigated with SEM and EDS.

\section{1. 1. Temperature: $50{ }^{\circ} \mathrm{C}$}

White spots (white rectangles in Figure 1a and EDS in Figure 2a) were detected as precipitants with a high oxygen content $(43 \%)$ in a $3: 1$ ratio with iron (16\%), which clearly indicates the formation of $\mathrm{FeCO}_{3}$, while at the same time a high chromium content was detected. Dark a)

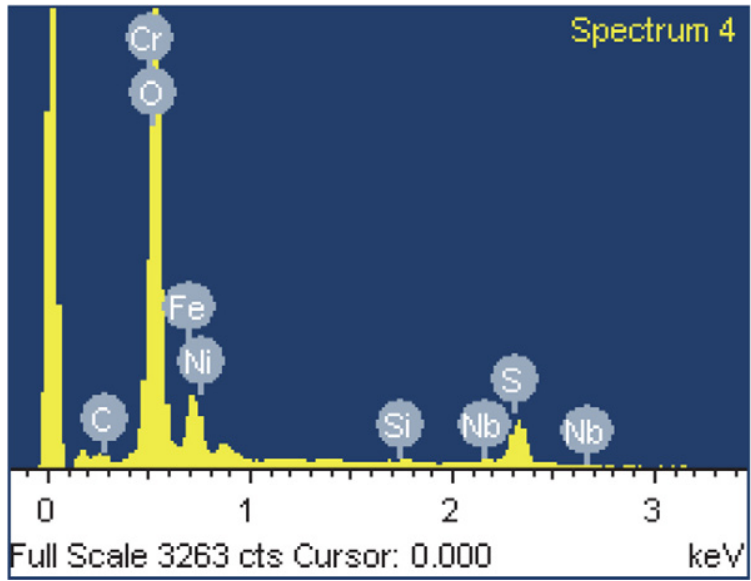

b)

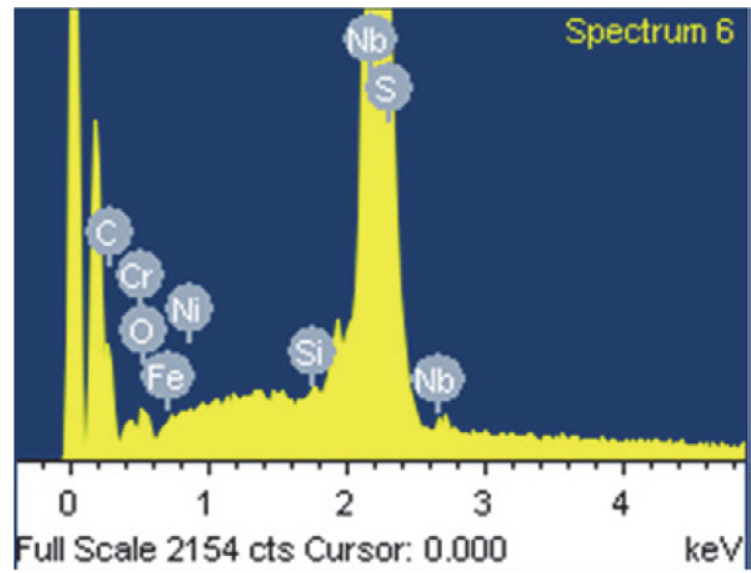

Figure 2. EDS results for AISI 347 from Figure 1a): a) white precipitants and b) dark area.

precipitants (red rectangle in Figure 1a and EDS in Figure $2 \mathrm{~b}$ ) indicate a high content of niobium (91\%). The sample treated at 300 bar (white rectangle in Figure 1b) shows large particles with a high content of oxygen (43\%), iron (16\%) and some chromium (13\%). Some large pits (red rectangle in Figure 1b) are also visible in the dark area (pitting corrosion). It was found, ${ }^{34}$ that the $\mathrm{FeCO}_{3}$ layer
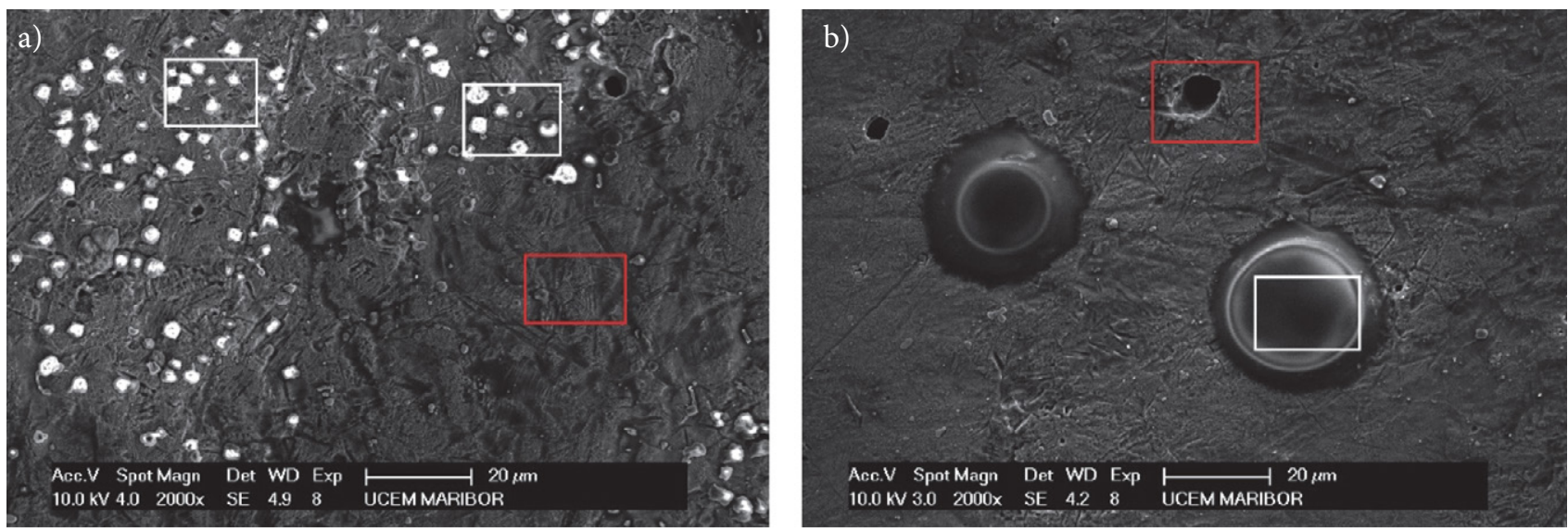

Figure1. SEM images for AISI 347 at $50{ }^{\circ} \mathrm{C}$ and pressure a) $100 \mathrm{bar}$ b) $300 \mathrm{bar}$. 
on the steel surface grows even in pits of locally corroded samples.

\section{1. 2. Temperature: $75^{\circ} \mathrm{C}$}

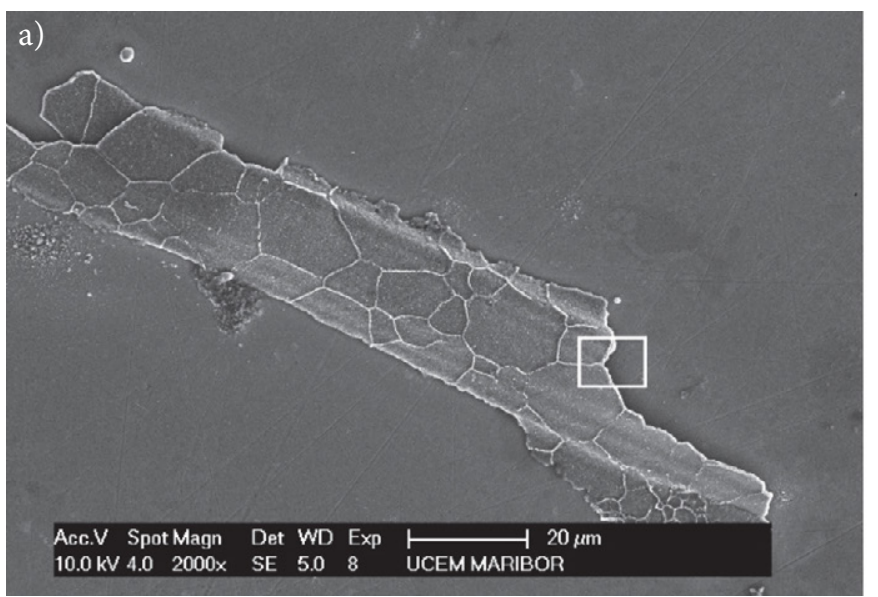

\section{2. Electrochemical Impedance Spectroscopy} (EIS)

The passivity imposed on the system by the potential difference has values between Flade potential and trans-

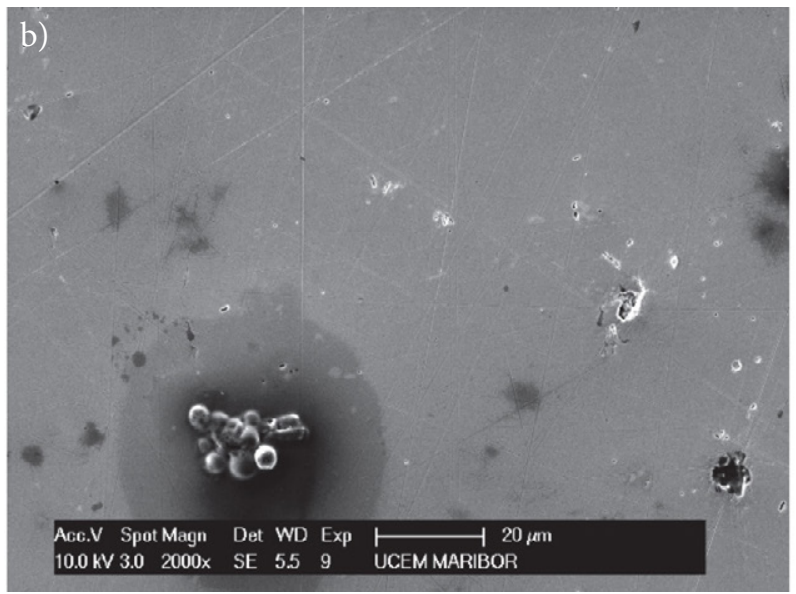

Figure 3. SEM images for AISI 347 at $75^{\circ} \mathrm{C}$ and pressure: a) 100 bar and b) 300 bar.
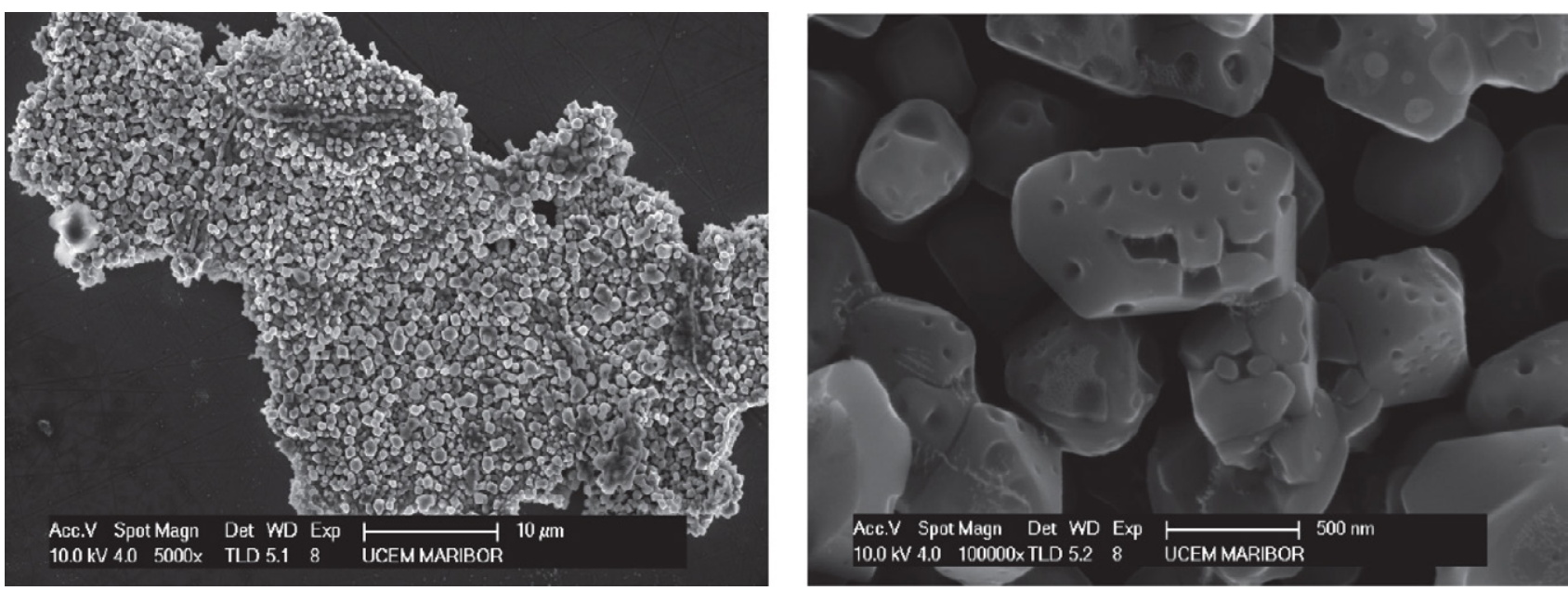

Figure 4. SEM images for AISI 347 at $75{ }^{\circ} \mathrm{C}$ and 100 bar at different magnifications (white borders from Figure 3).

At $75^{\circ} \mathrm{C}$ (Figures 3,4 ) and 100 bar some large structures of particles on the steel surface are visible. With EDS we detected high content of oxygen, iron and also chromium, in \%: $\mathrm{O} 35.40$, Fe 20.23 and $\mathrm{Cr} 41.82$. Apparently, iron and chromium oxides precipitated and niobium accelerates their formation in the passive layer. A formation shown in Figure $3 \mathrm{~b}\left(75^{\circ} \mathrm{C}\right.$ at 300 bar) was identified as a carbide. The EDS analysis shows a high content of carbon, in \%: C 29.18, O 12.85, Si 1.19, S 6.65, Cr 10.50, Fe 32.38, $\mathrm{Ni} 6.82$ and $\mathrm{Nb} 0.43$. In corrosion systems the carbides are always the worst option, as their formation leads to accelerated pitting corrosion. The formation of porous carbide layer in $\mathrm{CO}_{2}$ environments have been also reported by other authors. ${ }^{16,35,36}$ passivity potential. The effect of this process can be deduced from the resistance values, which decrease at the Flade potential and remain low and almost constant, and then increase sharply in the area of transpassivity. With EIS the passive layer can be examined at any potential value. Impedance curves, which are measured during the corrosion process, lead to the construction of equivalent circuits, which illustrate and evaluate chemical processes on the examined material. ${ }^{20,37,38}$

The RC equivalent circuit has been designed on the basis of the measured impedance curves shown in Fig. 5, where $R_{\mathrm{s}}$ represents the solution resistance, $R_{\mathrm{cl}}$ and $R_{\mathrm{ct}}$ the carbonate (pore) resistance and the charge transfer resistance, respectively. $Q_{\mathrm{cl}}$ and $Q_{\mathrm{dl}}$ are respectively $Q$ of the car- 


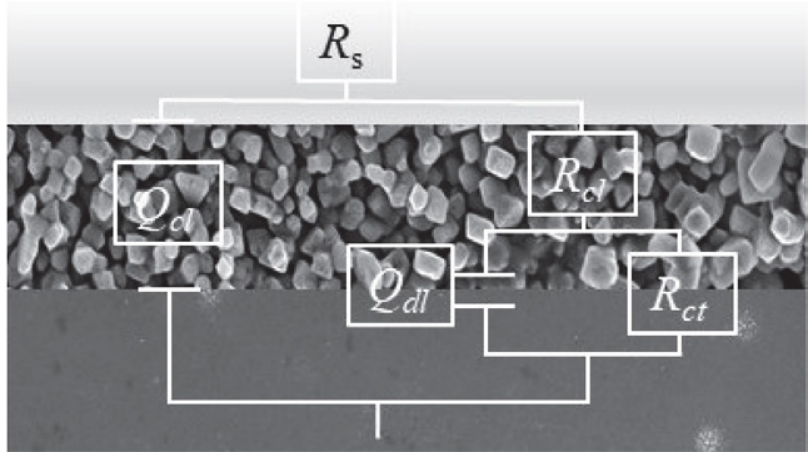

Figure 5. Equivalent circuit used for modelling the EIS results.

bonate (pore) and $Q$ of double layer. $Q$ is a frequency dependent element calculated from the CPE (constant phase element), which allows a better agreement between experimental and theoretical data.

The impedance of the $\mathrm{CPE}$ is defined: $:^{20,37}$

$$
Z_{C P E}=\left[Q(j \omega)^{\alpha}\right]^{-1}
$$

where $Z$ is the electrode impedance, the frequency independent constant $Q$ is a combination of properties related to the surface and the electroactive species, $\alpha$ is related to a slope of $\log Z$ vs. $\log f$ in the Bode plot, and is attributed to the surface heterogeneity, $\omega$ is the angular frequency. ${ }^{39}$

The parameter $Q\left(\mathrm{~s}^{\alpha} \Omega^{-1} \mathrm{~cm}^{-2}\right)$ can be converted to the capacitance $C\left(\mathrm{~s} \Omega^{-1} \mathrm{~cm}^{-1}\right)$ at $\alpha<1$ to quantitatively de-

a)

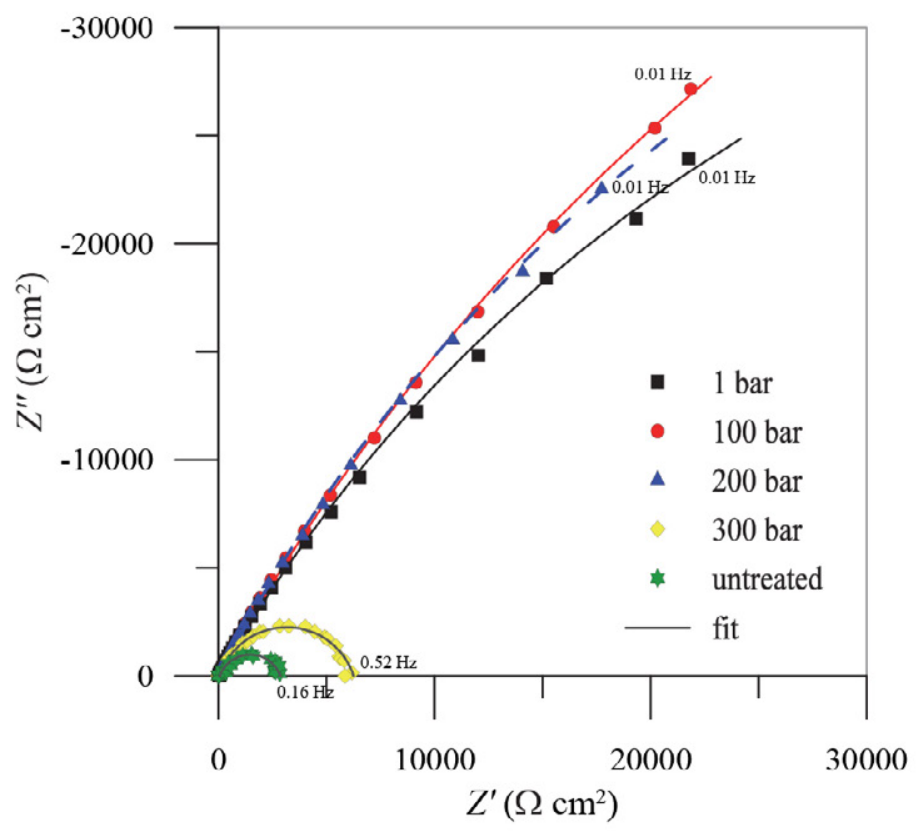

Figure 6. Impedance spectra for AISI 347 at $50^{\circ} \mathrm{C}$ : a) Nyquist plot, b) and c) Bode plot termine the system parameters, in particular the thickness, which is inversely proportional to the capacitance. When $a$ $=1, Q$ simply represents capacitance $C^{40}$

Nyquist diagrams (Figures 6 and 7) show curves for samples treated at 1,100 and 200 bar, which are typical for passive systems with high impedance values, and show two time constants, while the curves at 300 bar and untreated samples show classic semi-circular shapes. For the data collected for untreated steel and for sample at $50{ }^{\circ} \mathrm{C}$ and 300 bar, only one time constant is visible in the impedance diagram. The high frequency part of the diagram can refer to the $\mathrm{FeCO}_{3}$ layer or even to the mixture of $\mathrm{FeCO}_{3}$ and $\mathrm{F}_{3} \mathrm{C}$ carbide layers, which was also detected by other authors. ${ }^{16,36,41}$ They all have proved that $\mathrm{FeC}_{3}$ can act as a substrate for iron carbonate precipitation.

The low frequency part corresponds to the charge transfer process. From Figures 6 and 7 it can be seen that the highest charge transfer resistance shows steel treated at $100 \mathrm{bar}$, lower, but still similar are the values for samples treated at 1 and $200 \mathrm{bar}$, while the $R_{\mathrm{ct}}$ value for the $300 \mathrm{bar}$ sample decreases significantly, but is still slightly higher than for untreated steel.

Data from equivalent circuits are collected in Table 1.

The comparison between the working temperatures is clear and to be expected: temperature accelerates corrosion, which is expressed in lower impedance values and lower $R_{\mathrm{ct}}$ values, Figure 8 .

b)

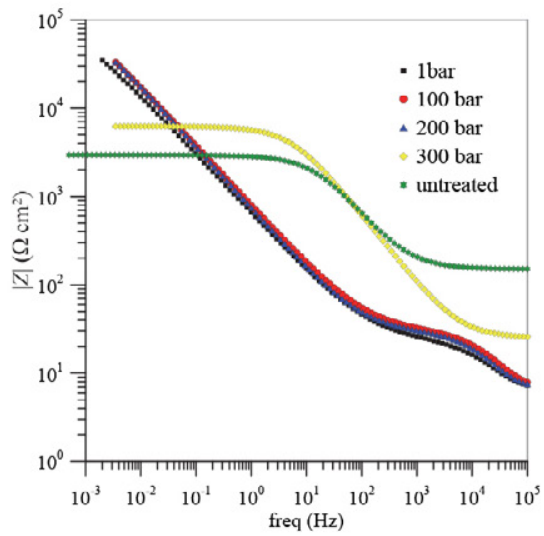

c)

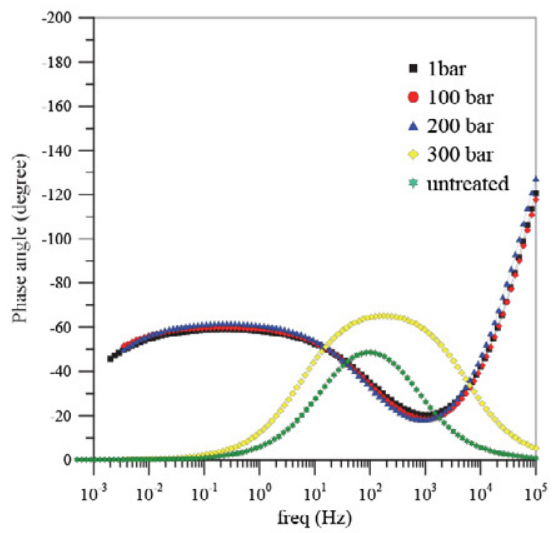




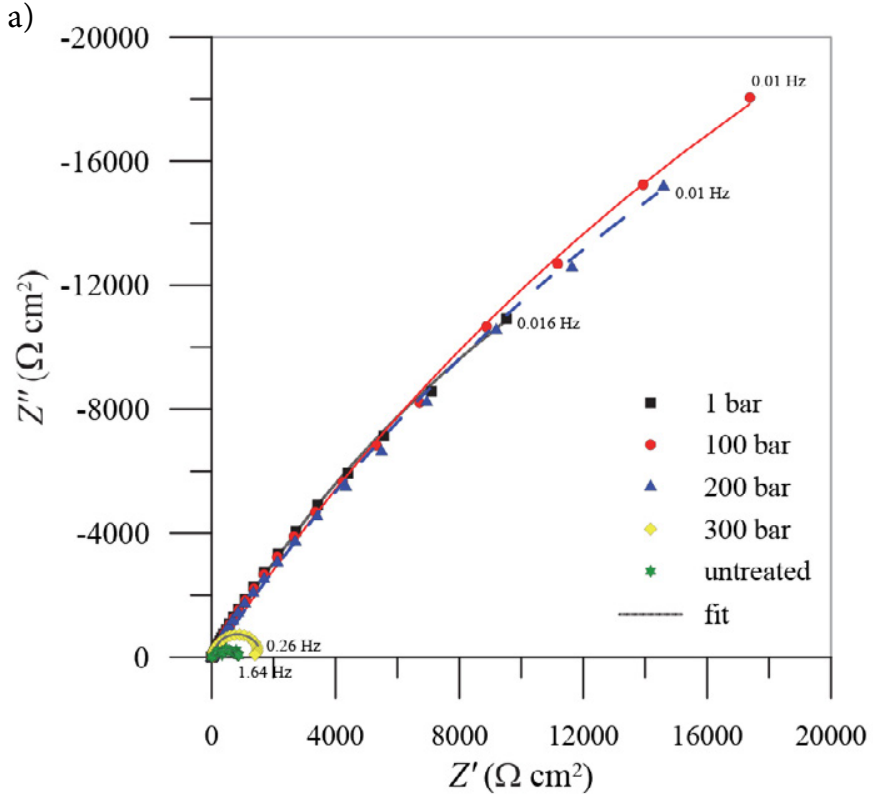

Figure 7. Impedance spectra for AISI 347 at $75^{\circ} \mathrm{C}$ : a) Nyquist plot, b) and c) Bode plot

Table 1. Parameter values from EIS measurements for AISI 347 at 50 and $75^{\circ} \mathrm{C}$.

\begin{tabular}{cccccccc}
\hline & $\begin{array}{c}\boldsymbol{P} \\
(\mathbf{b a r})\end{array}$ & $\begin{array}{c}\boldsymbol{R}_{\mathbf{p o}} \\
\left(\Omega \mathbf{c m}^{\mathbf{2}}\right)\end{array}$ & $\begin{array}{c}\mathbf{Q}_{\boldsymbol{c}} \cdot \mathbf{1 \mathbf { 1 0 } ^ { - 6 }} \\
\left(\mathbf{s}^{\alpha} \Omega^{-\mathbf{1}} \mathbf{c m}^{-\mathbf{2}}\right)\end{array}$ & $\alpha$ & $\begin{array}{c}\boldsymbol{R}_{\mathrm{ct}} \\
\left(\mathbf{k} \Omega \mathbf{c m}^{2}\right)\end{array}$ & $\begin{array}{c}\boldsymbol{Q}_{d l} \cdot \mathbf{1 0}^{-\mathbf{6}} \\
\left(\mathbf{s}^{\alpha} \Omega^{-\mathbf{1}} \mathbf{c m}^{-\mathbf{2}}\right)\end{array}$ & $\alpha$ \\
\hline $50^{\circ} \mathrm{C}$ & 1 & 34 & 8.40 & 0.71 & 120 & 440 & 0.67 \\
& 100 & 39 & 3.78 & 0.77 & 170 & 360 & 0.68 \\
& 200 & 38 & 4.00 & 0.78 & 130 & 370 & 0.76 \\
& 300 & & & & 6.20 & 9.20 & 0.80 \\
& untreated & & & & 2.80 & 9.99 & 0.77 \\
\hline $75{ }^{\circ} \mathrm{C}$ & 1 & 60 & 93 & 0.80 & 68 & 750 & 0.65 \\
& 100 & 56.27 & 3.7 & 0.76 & 110 & 650 & 0.63 \\
& 45 & 1.3 & 0.98 & 95 & 700 & 0.63 \\
& 300 & 38 & 0.46 & 0.98 & 1.6 & 67 & 0.95 \\
& & & & 0.83 & 22.6 & 0.65 \\
\hline
\end{tabular}

b)

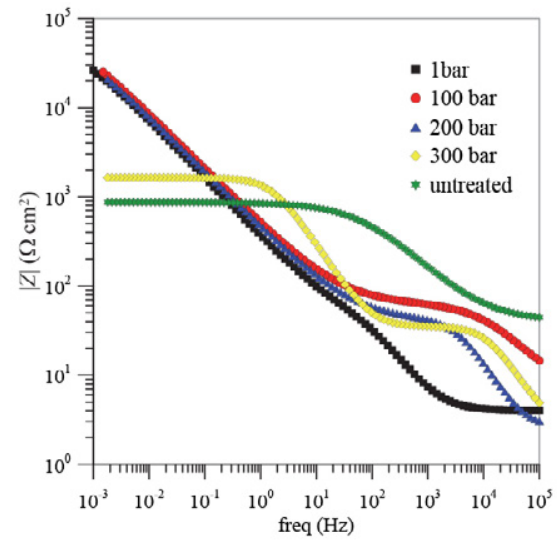

c)

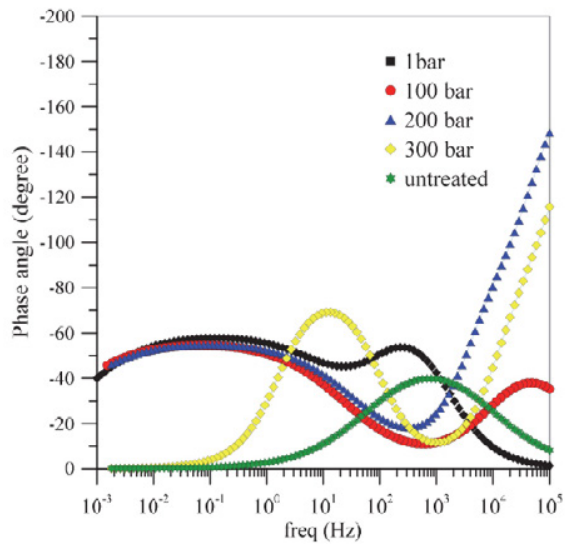

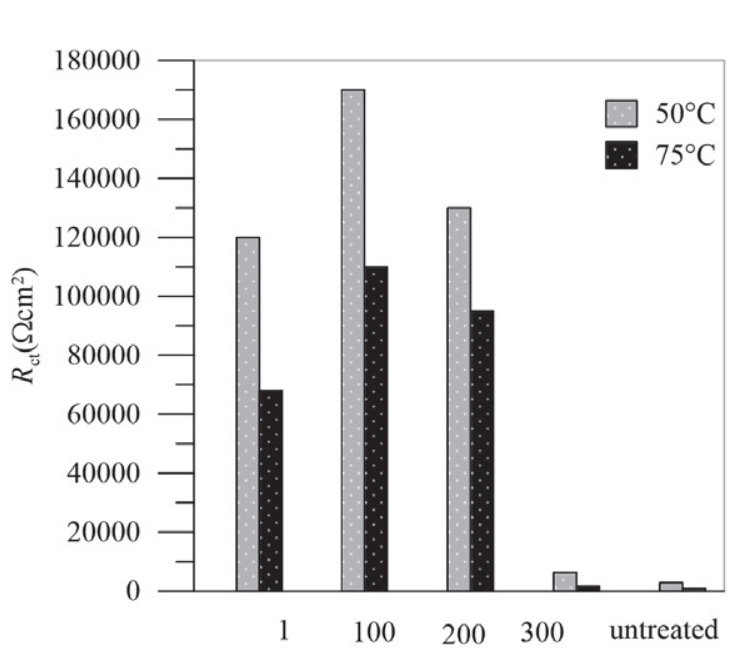

Figure 8. Calculated charge transfer resistance for AISI 347 at 50 and $75^{\circ} \mathrm{C}$ depending on the pressure treatment.

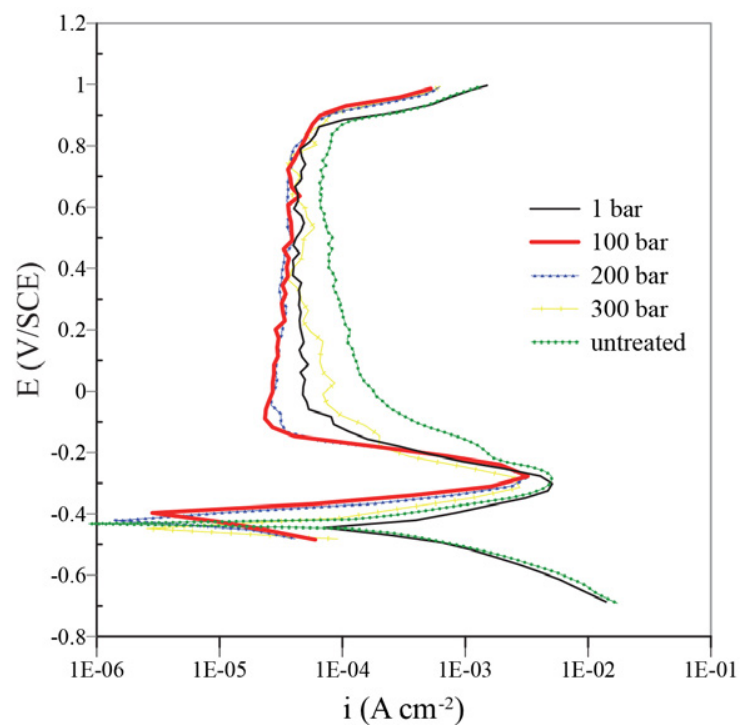

Figure 9. Polarization curves for AISI 347 at $50^{\circ} \mathrm{C}$. 
Table 2. Parameter values from potentiodynamic curves for AISI 347.

\begin{tabular}{|c|c|c|c|c|c|c|c|}
\hline & $\begin{array}{c}P \\
\text { (bar) }\end{array}$ & $\begin{array}{l}i_{\text {corr }} \cdot 10^{-5} \\
\left(\mathrm{~A} \mathrm{~cm}^{-2}\right)\end{array}$ & $\begin{array}{l}i_{\text {crit }} \cdot 10^{-3} \\
\left(\mathrm{~A} \mathrm{~cm}^{-2}\right)\end{array}$ & $\begin{array}{c}E_{\text {pas }} \\
(\mathrm{V} / \mathrm{SCE})\end{array}$ & $\begin{array}{c}E_{\text {trans }} \\
(\mathrm{V} / \mathrm{SCE})\end{array}$ & $\begin{array}{c}E_{\text {pas }}-E_{\text {trans }} \\
\text { (V/SCE) }\end{array}$ & $\begin{array}{c}r_{\text {corr }} \\
\left(\mathbf{m m} \mathbf{~ y}^{-1}\right)\end{array}$ \\
\hline \multirow[t]{5}{*}{$50^{\circ} \mathrm{C}$} & 1 & 1.680 & 2.80 & -0.130 & 0.794 & 0.924 & 0.196 \\
\hline & 100 & 0.821 & 3.53 & -0.164 & 0.831 & 0.996 & 0.096 \\
\hline & 200 & 1.174 & 3.36 & -0.154 & 0.812 & 0.966 & 0.137 \\
\hline & 300 & 9.372 & 2.89 & -0.144 & 0.768 & 0.912 & 1.090 \\
\hline & untreated & 13.05 & 5.10 & -0.048 & 0.759 & 0.804 & 1.525 \\
\hline \multirow[t]{5}{*}{$75^{\circ} \mathrm{C}$} & 1 & 5.624 & 4.67 & -0.171 & 0.739 & 0.910 & 0.657 \\
\hline & 100 & 2.744 & 1.87 & -0.175 & 0.748 & 0.924 & 0.320 \\
\hline & 200 & 4.600 & 4.56 & -0172 & 0.741 & 0.913 & 0.537 \\
\hline & 300 & 15.24 & 1.33 & -0164 & 0.738 & 0.902 & 1.780 \\
\hline & untreated & 22.08 & 9.86 & -0.013 & 0.731 & 0.744 & 2.581 \\
\hline
\end{tabular}

\section{3. Potentiodynamic Polarization}

From polarization curves presented in Figure 9 (example at $50^{\circ} \mathrm{C}$ ), the parameters listed in Table 2 were read out.

On the basis of Tafel extrapolation ${ }^{42}$ from corrosion currents, $i_{\text {corr }}$ corrosion rates in $\mathrm{mm}$ per year were calculated, which are listed in Table 2 and also shown in Figure 10 including values for the corrosion rates at $25^{\circ} \mathrm{C} .{ }^{30}$ The $E_{\text {pas }}$ values are the highest (shifted towards more positive values) for a sample treated at $100 \mathrm{bar}$, these samples also show the lowest $i_{\text {corr }}$, the largest passive range $\left(E_{\text {pas }}-E_{\text {trans }}\right)$ and the lowest corrosion rates.

From Figure 10, we can determine the best results for measured system at $50{ }^{\circ} \mathrm{C}$ and 100 bar.

As explained in the Introduction section, the growth of the $\mathrm{FeCO}_{3}$ layer occurs only after the saturation concentration is exceeded, and this requires a higher temperature,

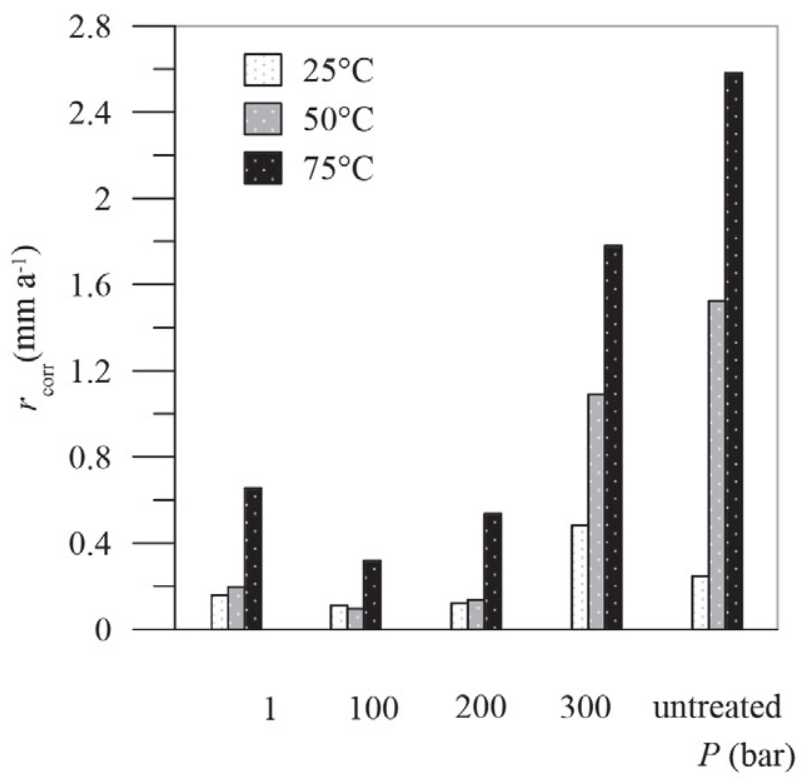

Figure 10. Corrosion rate for AISI 347 at $25^{30}, 50$ and $75^{\circ} \mathrm{C}$ in dependence of pressure.
$>60{ }^{\circ} \mathrm{C} .{ }^{20}$ This means that obviously at this combination $25^{\circ} \mathrm{C}$ and $100 \mathrm{bar}$, is still a low temperature, which implies that the corrosion rate is higher than the rate of $\mathrm{FeCO}_{3}$ precipitation. At $50{ }^{\circ} \mathrm{C}$ and 100 bar, the circumstances of precipitation are so favourable that the corrosion rate is lower. At $75^{\circ} \mathrm{C}$ and 100 bar, the temperature is so high that it accelerates the corrosion rate regardless of the $\mathrm{FeCO}_{3}$ precipitation rate.

\section{4. Activation Energy Calculation}

The temperature dependence of the corrosion current density at different pressure values was further determined. Data at $25^{\circ} \mathrm{C}$ (published in earlier work ${ }^{30}$ ), 50 and $75^{\circ} \mathrm{C}$ were considered. The values of the activation energy were calculated using the Arrhenius equation: ${ }^{43,44}$

$$
\ln i_{\text {corr }}=\ln A-\frac{E_{a}}{R T}
$$

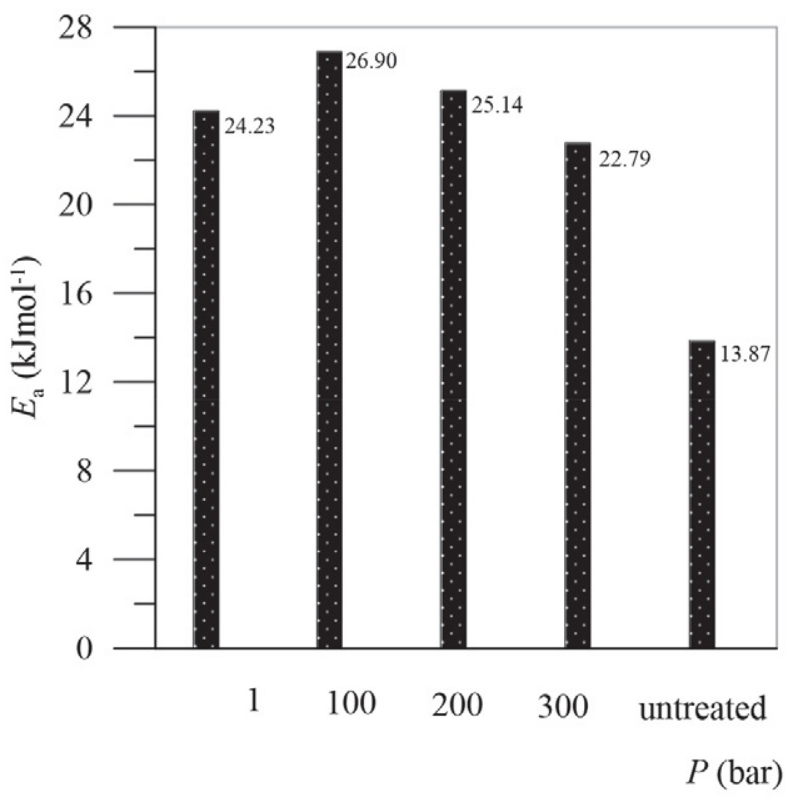

Figure 11. Activation energy values for AISI 347 in dependence of pressure treatment. 
where $\mathrm{A}$ is pre-exponential factor, $E_{a}$ is activation energy and $R$ is a gas constant. Activation energy values are given in Figure 11.

The activation energy represents the minimum energy that the reactants must have to form a product. In our case, the passive layer has already been formed, so that the activation energy can be related to the process of dissolving the layer. From the data obtained it can be concluded that the highest corrosion rate would be that of untreated steel, since the process of dissolution of the passive layer requires a minimum energy of $13.87 \mathrm{~kJ} / \mathrm{mol}$, unlike steel treated at $100 \mathrm{bar}$, which has the highest value of activation energy of $26.9 \mathrm{~kJ} / \mathrm{mol}$ and would therefore corrode at the lowest rate.

\section{Discussion}

SEM images and in especially EDS analyses show that at 100 bar and $50^{\circ} \mathrm{C}$ treated steel (which indicates the best corrosion results) the content of oxygen incorporated in the passive layer to build up protective compounds increases by up to $30 \mathrm{wt} \%$ determined on a dark, more or less uniformly corroded surface, without precipitates.

At $50{ }^{\circ} \mathrm{C}$, the oxygen content increases considerably: from 2 to $9 \mathrm{wt} . \%$ and the carbon content increases from 1.1 to $2.3 \mathrm{wt} . \%$. The oxygen content in precipitated white particles increases up to $43 \mathrm{wt} . \%$ (in relation to $\mathrm{Fe}-15.8$ wt.\%, which clearly indicates the formation of $\mathrm{FeCO}_{3}$, and the chromium content also increases up to $20 \mathrm{wt} . \%$, (Figure 1a). By increasing the operating temperature to $75^{\circ} \mathrm{C}$ of the sample treated at $100 \mathrm{bar}$, the oxygen content decreases to $35 \mathrm{wt} . \%$ but at the same time increases the carbon content. For the sample treated at 300 bar, which indicates the highest corrosion rate between the treated samples, the EDS data are as follows: the oxygen content on the dark surface decreased from $24.7 \%$ at $50{ }^{\circ} \mathrm{C}$ to $1.7 \%$ at $75{ }^{\circ} \mathrm{C}$. White precipitates, which are clearly visible in Figures $2 \mathrm{~b}$ ) and $3 \mathrm{~b}$ ), contain $41.4 \mathrm{wt} . \%$ oxygen at $50^{\circ} \mathrm{C}$, which decreases to $8 \mathrm{wt} . \%$ at $75^{\circ} \mathrm{C}$, while the carbon content increases from $0.46 \mathrm{wt} . \%$ to $9.5 \mathrm{wt} . \%$ as the temperature rises. A significant pressure increase obviously leads to an accelerated precipitation of carbon or carbon compounds.

It is obvious that the corrosion behaviour at increasing pressure and temperature depends on the $\mathrm{FeCO}_{3}$ precipitation mechanism. Choi et al. ${ }^{45}$ found that the concentrations of $\mathrm{CO}_{2}, \mathrm{H}_{2} \mathrm{CO}_{3}$ and $\mathrm{HCO}_{3}{ }^{-}$in the water $-\mathrm{CO}_{2}$ system for transport pipelines increase with increasing pressure but decrease with increasing temperature. The solubility of $\mathrm{CO}_{2}$ in water reaches its almost lowest value at $55^{\circ} \mathrm{C}$ (compared to 55 and $75^{\circ} \mathrm{C}$ ) and 100 bar. It was also found that the reduced grain size of $\mathrm{FeCO}_{3}$ forms a denser and therefore more efficient protective layer. These results are also in good agreement with our findings. The comparison between images a) and b) in Fig. 1 shows the small grain sizes that have grown at 100 bar compared to the large gain size at $300 \mathrm{bar}$, indicating slower layer growth at 300 bar, which leads to a porous layer and thus to a higher corrosion rate. Pfennig et al. ${ }^{32}$ also confirmed that the corrosion rates at 100 bar are lower compared to the ambient pressure, assuming that this could be due to an open capillary system within the corrosion layer that is not present in the high pressure system and thus prevents rapid mutual diffusion of the ionic species. We can assume that at 1 and 200 bar the mechanism of protective layer growth is the same as at 100 bar, as also indicated by Zhang et al. ${ }^{26}$ (studied at 10 and 95 bar). One would expect the corrosion rate to decrease steadily with pressure, but at 300 bar it changes significantly. At high pressures, the amount of $\mathrm{CO}_{2}$ dissolved in water and some other $\mathrm{CO} 2$ properties should be considered, for example the compressibility factor.

The compressibility factor for $\mathrm{CO}_{2}$, calculated with a modified Redlich-Kwong equation according to Spycher et at. ${ }^{46}$ and Lemmon at al ${ }^{47}$ showed the lowest value exactly between 100 and 200 bar at about $50^{\circ} \mathrm{C}$ compared to about $70{ }^{\circ} \mathrm{C}$. At 300 and up to $600 \mathrm{bar}$ it increases linearly. At 100 bar, the value of the compressibility factor is about 0.38 compared to $300 \mathrm{bar}$, which indicates a value of 0.6 , meaning that at 300 bar the $\mathrm{CO}_{2}$ molecules collide more often and hardly move at all. This can explain the slower diffusion and thus the formation of a porous layer with large particles which consequently leads to a high corrosion rate.

\section{Conclusions}

In this study the corrosion behaviour of AISI 347 in $0.1 \mathrm{M}$ sulphuric acid at temperatures of 50 and $75^{\circ} \mathrm{C}$ and pressures 1, 100, 200 and 300 bar in $\mathrm{CO}_{2}$ atmosphere was investigated. An increased pressure significantly reduced the corrosion rate compared to untreated steel. The decisive points of our contribution are:

A surface analysis was used to detect both the $\mathrm{FeCO}_{3}$ layers and the precipitated grains, whose size varies according to the $\mathrm{CO}_{2}$ pressure level.

The corrosion rate determined by electrochemical methods decreases from 1 to $200 \mathrm{bar}$, is lowest at $100 \mathrm{bar}$, but increases significantly at 300 bar.

We attribute this sudden change to a compressibility factor of the $\mathrm{CO}_{2}$, which allows us to explain the movement and collision of the molecules with each other, leading to their slower diffusion and consequently to the formation of a porous layer with large grains, which is noticeable as an increase in the corrosion rate.

The best conditions for the lowest corrosion rate were found at $50^{\circ} \mathrm{C}$ and 100 bar. This combination shows the following results:

A small grain size precipitates, causing them to adhere closely together, resulting in a denser and ticker protective layer of $\mathrm{FeCO}_{3}$, which is therefore more resistant to further dissolution. 
Charge transfer resistance showed the highest value, which confirmed the lowest corrosion rate.

The activation energy for dissolution of the protective layer showed the highest value, confirming the best passivation.

All conclusions are in good agreement with the value of the compressibility factor of $\mathrm{CO}_{2}$ at 100 bar, which allows us to explain the movements of its molecules on which the formation and the properties of the protective layer depend.

\section{Acknowledgements}

This work was supported by Slovenian Research Agency, grant P2-006.

\section{References}

1. A. Assarian, S. M., Improving Polyaspartic Anti-Corrosion Coating Protective Properties with the use of Nano-silica. Acta Chim. Slov. 2018, 65, 569-577.

DOI:10.17344/acsi.2018.4187

2. Itman Filho, A.; Silva, R.; Cardoso, W.; Casteletti, L. C., Effect of Niobium in the Phase Transformation and Corrosion Resistance of One Austenitic-ferritic Stainless Steel. Materials Research 2014, 17, 801-806.

DOI:10.1590/1516-1439.190113

3. A. C. Gonzaga, C. Barbosa, S. S. M. Tavares, A. Zeemann, J. C. Payão, Influence of post welding heat treatments on sensitization of AISI 347 stainless steel welded joints. Journal of Materials Research and Technology 2020, 9 (1), 908-921.

DOI:10.1016/j.jmrt.2019.11.031

4. S. Y. Huang, W.-T. Tsai, Y.-T.Pan, J.-C. Kuo, H.-W. Chen, Lin, Effect of Niobium Addition on the High-Temperature Oxidation Behavior of $22 \mathrm{Cr} 25 \mathrm{NiWCoCu}$ Stainless Steel in Air. Metals - Open Access Metallurgy Journal 2019, 9, 975.

DOI:10.3390/met9090975

5. M. F. Morks, P. Corrigan, N. Birbilis, I. S. Cole, A green Mn$\mathrm{MgZn}$ phosphate coating for steel pipelines transporting $\mathrm{CO}_{2}$ rich fluids. Surface and Coatings Technology 2012, 210, 183189. DOI:10.1016/j.surfcoat.2012.09.018

6. M. F. Morks, N. F. Fahim, T. H. Muster, I. S. Cole, Cu-based Fe phosphate coating and its application in $\mathrm{CO}_{2}$ pipelines. Surface and Coatings Technology 2013, 228, 167-175.

DOI:10.1016/j.surfcoat.2013.04.025

7. Q.-Y. Wang, X.-Z. Wang, H. Luo, J.-L. Luo, A study on corrosion behaviors of $\mathrm{Ni}-\mathrm{Cr}-\mathrm{Mo}$ laser coating, 316 stainless steel and X70 steel in simulated solutions with $\mathrm{H} 2 \mathrm{~S}$ and CO2. Surface and Coatings Technology 2016, 291, 250-257.

DOI:10.1016/j.surfcoat.2016.02.017

8. Y. Zhao, W. Liu, W. Banthukul, Y. Fan, X. Li, Effect of silty sand on the pre-passivation behaviour of $1 \mathrm{Cr}$ steel in a $\mathrm{CO}_{2}$ aqueous environment. Corrosion Engineering, Science and Technology 2020, 55 (3), 205-216.

DOI:10.1080/1478422X.2020.1713533
9. H. Cen, J. Cao, Z. Chen, X. Guo, 2-Mercaptobenzothiazole as a corrosion inhibitor for carbon steel in supercritical CO2H2O condition. Applied Surface Science 2019, 476, 422-434. DOI:10.1016/j.apsusc.2019.01.113

10. H.-H. Zhang, X. Pang, K. Gao, Localized $\mathrm{CO}_{2}$ corrosion of carbon steel with different microstructures in brine solutions with an imidazoline-based inhibitor. Applied Surface Science 2018, 442, 446-460. DOI:10.1016/j.apsusc.2018.02.115

11. A. Singh, Y. Lin, K. R. Ansari, M. A. Quraishi, E.E. Ebenso, S. Chen, W. Liu, Electrochemical and surface studies of some Porphines as corrosion inhibitor for J55 steel in sweet corrosion environment. Applied Surface Science 2015, 359, 331-339. DOI:10.1016/j.apsusc.2015.10.129

12. D. A. López, T. Pérez, S. N. Simison, The influence of microstructure and chemical composition of carbon and low alloy steels in $\mathrm{CO}_{2}$ corrosion. A state-of-the-art appraisal. Materials \& Design 2003, 24 (8), 561-575.

DOI:10.1016/S0261-3069(03)00158-4

13. A. Dugstad, Fundamental Aspects of $\mathrm{CO}_{2}$ Metal Loss Corrosion - Part 1: Mechanism. NACE - International Corrosion Conference Series 2006, 2015.

14. A. Dugstad, The Importance of FeCO3 Super-saturation on $\mathrm{CO}_{2}$ Corrosion of Carbon Steels CORROSION/1992, Paper No.14, (Houston, TX: NACE International, 1992)

15. A. Dugstad, H. H., M. Seiersten, Effect of Steel Microstructure on Corrosion Rate and Protective Iron Carbonate Film Formation. Corrosion 2001, 47 (4), 369-378. DOI: $10.5006 / 1.3290361$

16. A. Dugstad, Mechanism of protective film formation during $\mathrm{CO}_{2}$ corrosion of carbon steel. Corrosion/98 1998, (Paper no. 31), NACE, Huston, TX.

17. J. K. Heuer, J. F. Stubbins, An XPS characterization of $\mathrm{FeCO}_{3}$ films from $\mathrm{CO}_{2}$ corrosion. Corrosion Science 1999, 41 (7), 1231-1243. DOI:10.1016/S0010-938X(98)00180-2

18. W. Sun, S. Nesic, Basics Revisited: Kinetics of Iron Carbonate Scale Precipitation in $\mathrm{CO}_{2}$ Corrosion. In CORROSION 2006, NACE International: San Diego, California, 2006; p 21.

19. S. N. Yoon-Seok Choi, Corrosion Behavior Of Carbon Steel In Supercritical $\mathrm{CO}_{2}$-Water Environments. CORROSION 2009, 22-26 March, Atlanta, Georgia 2009.

20. S. Nešić, K. L. J. Lee, A Mechanistic Model for Carbon Dioxide Corrosion of Mild Steel in the Presence of Protective Iron Carbonate Films-Part 3: Film Growth Model. Corrosion 2003, 59 (7), 616-628. DOI:10.5006/1.3277592

21. W. Sun, S. Nešić, R.C. Woollam, The effect of temperature and ionic strength on iron carbonate $\left(\mathrm{FeCO}_{3}\right)$ solubility limit. Corrosion Science 2009, 51 (6), 1273-1276.

DOI:10.1016/j.corsci.2009.03.009

22. S. Nešić, Key issues related to modelling of internal corrosion of oil and gas pipelines - A review. Corrosion Science 2007, 49 (12), 4308-4338. DOI:10.1016/j.corsci.2007.06.006

23. C. De Waard, D. E. Milliams, Carbonic Acid Corrosion of Steel. CORROSION 1975, 31 (5), 177-181.

DOI:10.5006/0010-9312-31.5.177

24. S. Nešić, S. W. Keith George, High Pressure $\mathrm{CO}_{2}$ Corrosion Electrochemistry and the Effect of Acetic Acid. CORROSION 
2004, 28 March-1 April, New Orleans, Louisiana 2004.

25. Y. Sun, S. Nešić, A parametric study and modeling on localized $\mathrm{CO}_{2}$ corrosion in horizontal wet gas flow. NACE Meeting Papers 2004.

26. Y. Zhang, X. Pang, S. Qu, X. Li, K. Gao, Discussion of the $\mathrm{CO}_{2}$ corrosion mechanism between low partial pressure and supercritical condition. Corrosion Science 2012, 59, 186-197. DOI:10.1016/j.corsci.2012.03.006

27. X. Li,; Y. Zhao, W. Qi, J. Xie, J. Wang, B. Liu, G. Zeng, T. Zhang, F. Wang, Effect of extremely aggressive environment on the nature of corrosion scales of HP-13Cr stainless steel. Applied Surface Science 2019, 469, 146-161.

DOI:10.1016/j.apsusc.2018.10.237

28. Z. M. Wang, X. Han, J. Zhang, Z. L. Wang, In situ observation of $\mathrm{CO}_{2}$ corrosion under high pressure. Corrosion Engineering, Science and Technology 2014, 49 (5), 352-356.

DOI:10.1179/1743278213Y.0000000144

29. I. Milošev, Contemporary Modes of Corrosion Protection and Functionalization of Materials. Acta Chimica Slovenica 2019, 66, 511-533. DOI:10.17344/acsi.2019.5162

30. M. Slemnik; D. Pečar, High-pressure $\mathrm{CO}_{2}$ pretreatment as a method for stainless steel passivation. Anti-Corrosion Methods and Materials 2010, 57 (6), 290-296.

DOI:10.1108/00035591011087145

31. ZView, ZPlot, CorrView, CorrWare, version 2.8. Scribner Associates, Inc, Southern Pines, NCD, USA 1990-1999.

32. A. Pfennig, A. Kranzmann, Effect of $\mathrm{CO}_{2}$ and pressure on the stability of steels with different amounts of chromium in saline water. Corrosion Science 2012, 65, 441-452.

DOI:10.1016/j.corsci.2012.08.041

33. G. Zhang, M. L.C. Chai, Y. Wu, Effect of $\mathrm{HCO}_{3}{ }^{-}$concentration on $\mathrm{CO}_{2}$ corrosion in oil and gas fields. Journal of University of Science and Technology Beijing, Mineral, Metallurgy, Material 2006, 13 (1), 44-49.

DOI:10.1016/S1005-8850(06)60012-1

34. A. Pfennig, A. Kranzmann, The Role Of Pit Corrosion In Engineering The Carbon Storage Site At Ketzin, Germany. WIT Transactions on Ecology and the Environment 2010, 136, 109-119. DOI:10.2495/AIR100101

35. Staicopolus, N., The role of cementite in the acidic corrosion of steel. J. Electochem. Soc. 1963, 110.

DOI:10.1149/1.2425602

36. S. Al-Hassan, B. Mishra, D. L. Olson, M. M. Salama, , Effect of microstrucure on corrosion of steels in aquerous solutions containing carbin dioxide. Corrosion 1998, 54 (6), 480.

DOI: $10.5006 / 1.3284876$

37. A. S. Hamdy, E. El-Shenawy. T. El-Bitar, Electrochemical Impedance spectroscopy of the corrosion behaviour of some niobium bearing stainless steels in $3.5 \% \mathrm{NaCl}$. International Journal of Electrochemical Science 2006, Vol.1, 171-180.

DOI:10.1016/j.matlet.2006.10.043

38. Z. Tan, L. Yang, D. Zhang, Z. Wang, F. Cheng, M. Zhang, Y. Jin, Development mechanism of internal local corrosion of X80 pipeline steel. Journal of Materials Science \& Technology 2020, 49, 186-201. DOI:10.1016/j.jmst.2019.10.023

39. M. E. Orazem, I. Frateur, B. Tribollet, V. Vivier, S. Marce- lin, N. Pebere, A.L. Bunge, E. A.White, D.P. Riemer, M. Musiani, Dielectric Properties of Materials Showing Constant-Phase-Element (CPE) Impedance Response. Journal of The Electrochemical Society 2013, 160 (6), C215-C225.

DOI:10.1149/2.033306jes

40. B. Hirschorn, M. E. Orazem, B. Tribollet, V. Vivier, I. Frateur, M. Musiani, Determination of effective capacitance and film thickness from constant-phase-element parameters. Electrochimica Acta 2010, 55 (21), 6218-6227.

DOI:10.1016/j.electacta.2009.10.065

41. F. Farelas, M. Galicia, B. Brown, S. Nesic, H. Castaneda, Evolution of dissolution processes at the interface of carbon steel corroding in a $\mathrm{CO}_{2}$ environment studied by EIS. Corrosion Science 2010, 52 (2), 509-517.

DOI:10.1016/j.corsci.2009.10.007

42. Corrosion: Third Edition. Shreir, L. L.; Jarman, R. A.; Burstein, G. T., Eds. 1994; Vol. 1, pp 1-2815.

43. P. W. Atkins, Physical Chermistry. Eight ed.; Oxford University Press Oxford, USA, 2006.

44. F. Mohammadinejad, S. M. A. Hoseini, M. S. Zandi, M. J. Bahrami, Z. Golshani, Metoprolol: New and Efficient Corrosion Inhibitor for Mild Steel in Hydrochloric and Sulfuric Acid Solutions. Acta Chim. Slov. 2020, 67, 710-719.

DOI:10.17344/acsi.2019.5301

45. Y.-S. Choi, S. Nešić,, Determining the corrosive potential of $\mathrm{CO}_{2}$ transport pipeline in high $\mathrm{p}_{\mathrm{CO} 2}$ water environments. International Journal of Greenhouse Gas Control 2011, 5 (4), 788-797. DOI:10.1016/j.ijggc.2010.11.008

46. N. Spycher, K. Pruess, J. Ennis-King, $\mathrm{CO}_{2}-\mathrm{H}_{2} \mathrm{O}$ mixtures in the geological sequestration of $\mathrm{CO} 2$. I. Assessment and calculation of mutual solubilities from 12 to $100{ }^{\circ} \mathrm{C}$ and up to 600 bar. Geochimica et Cosmochimica Acta 2003, 67 (16), 3015-3031. DOI:10.1016/S0016-7037(03)00273-4

47. E. W. Lemmon, M. O. McLinden, D. G. Friend, National Institute of Standards and Technology, US, Thermophysical properties of fluid systems. 1998. 


\section{Povzetek}

S površinsko analizo in elektrokemijskimi metodami smo proučevali korozijske lastnosti jekla AISI $347 \mathrm{v} 0,1 \mathrm{M}$ raztopini žveplove kisline. Jeklo smo izpostavili $\mathrm{CO}_{2}$ atmosferi pri 50 in $75^{\circ} \mathrm{C}$ in tlakih vse do 300 barov. Prisotnost $\mathrm{CO}_{2}$ pospešuje nastanek zaščitne plasti iz $\mathrm{FeCO}_{3}$, vendar je uspešnost takšnega pasiviranja odvisna od njegove nasičenosti in ustrezne temperature. Ne samo podobni, celo boljši rezultati so bili doseženi pri nižjih temperaturah s povišanjem tlaka. Razlike v korozijski hitrosti med vzorci smo potrdili tudi z določitvijo vrednosti aktivacijskih energij, ki jih sistem potrebuje za nadaljnje raztapljanje zaščitne plasti. Predpostavimo lahko, da stisljivost $\mathrm{CO}_{2}$ pri različnih tlakih vpliva na poroznost zaščitne plasti železovega karbonata in posledično njenih korozijskih lastnosti. 